\title{
Space Experiences: Example of the Siğacık Settlement of the Citta Slow City Seferihisar, Turkey
}

\author{
Emine Malkoç True ${ }^{1}$, Çiğdem Kiliçaslan ${ }^{2}$
}

\begin{abstract}
The village of Siğactk attracts people with its castle, local products and narrow streets, along with its seaside lifestyle. The settlement is remarkable for its historical heritage, with an Ionian colony, founded approximately 1000 B.C, located $1 \mathrm{~km}$ south of the village. Siğacık, which is popular for its sights and tourist attractions, lies within the 'citta slow city' area of Seferibisar. For these reasons it was chosen as the research area and its open space experiences are examined in this study. The study was comprised of four main sections, namely; definition of the subject, data collection, results, evaluation and synthesis. After an initial search of the literature, a questionnaire form that evaluated the experience of the local people in relation to open spaces was prepared. The questionnaire was conducted with local people in Siğacik and the "Simple Random Sampling Method" was used to determine the number of users on which the questionnaire would be conducted, a $90 \%$ confidence level and 0.1 sampling error were taken as the basis of the calculations. In the calculation, the total population number of 2.329 was used as the "Population Size (N)" and the number of users on which questionnaire would be conducted was determined as 66 (65.77). The questionnaire was aimed at evaluating the open space experience in a 'citta slow city' area. As a result; the Siğacle settlement is livable $(62 \%)$ according to the local people. They are pleased to live in Siğacık (86\%) and are pleased from its popularity (68\%). They are thinking that being a Citta Slow City member influenced their life positively (58\%). Daily life passes outside the houses in general and outdoor life style which forms the identity of the settlement needs to be supported.
\end{abstract}

Keywords: Landscape architecture, Cittaslow city, Open space, Seferihisar, Turkey

\section{Introduction}

The influence of globalization has showed itself on cities which have turned into places that are designed to move and work faster and have become insufficient living spaces where people work fast, live fast and consume more than they produce. Cittaslow movement in urban areas rose, as the consumer wise life does not bring happiness and peace so that people are looking for a different way of life (Cittaslow Türkiye, 2015). Cittaslow, composed of the words "Citta" (City) in Italian and "Slow" in English, is used in the meaning of slow city (Afd, 2015) and defined as a local development model for small and livable cities (Vize Municipality, 2015).

The Cittaslow movement was established in Italy in 1999 when a group of Italian mayors along with Carlo Petrini the leader of the Slow Food movement decided to apply the principles of Slow Food to urban living. Cittaslow not only ascribes to the emphasis on local produce and food quality manifested in the 'eco-gastronomic' and environmentalist agenda of Slow Food, but also to a set of criteria for local urban governance aimed at improving local quality of life, maintaining local uniqueness and supporting sustainable urban economies (Pink, 2009). Cittaslow movement set its goals on purpose that the cities where people can communicate with each other and become social and which do not have infrastructure problems, use renewable energy sources, benefit from the technology, protect their traditions, nature and handicrafts, are sustainable and self - sustained, can be a realistic alternative for the cities of today's world (Cittaslow Turkey, 2015). Cittaslow, an organized network of small cities, is attempting to focus urban and regional

${ }^{1}$ Ege University, Landscape Architecture Department, Izmir, Turkey

2 Adnan Menderes University, Landscape Architecture Department, Aydın, Turkey 
plans around the primary asset of place based identity, by choosing to preserve the threads of each urban area's own unique characteristics (Radstrom, 2011). A slow city agrees to work towards a set of goals that aim to improve the quality of life of its citizens and its visitors, and to share good ideas, experiences and knowledge across the national and international Cittaslow networks (Miele, 2008). Cittaslow International Network consists of 192 cities present in 30 Countries in the World (Cittaslow.org, 2015).

To be eligible for membership, candidate cities must have no more than 50.000 inhabitants and must pledge to introduce a range of measures from the promotion of organic agriculture to the creation of centres where visitors can sample local traditional food. They must also take steps to protect the sources and purity of the raw ingredients and to fend off the advance of fast food and cultural standardization. Membership of the Cittaslow movement is carefully controlled, and cities are admitted to membership only after trained local 'operatives' have prepared an initial report on the city's commitment to Slow City principles (Knox, 2005). The six main components of Cittaslow policy are: Environmental Policies, Infrastructure Policies, Technologies and Facilities for Urban Quality, Safeguarding Autochthonous Production, Awareness and Hospitality. These areas go beyond a basic slow philosophy to practical ways of improving the quality of life for residents, through environmental and place sustaining means (Radstrom, 2011). The Slow City movement aims to protect and enhance urban livability and quality of life. Slow Cities are places where citizens and local leaders pay attention to local history and utilize the distinct local context to develop in better and more sustainable ways (Mayer and Knox, 2006).

Being the first town in Turkey, which achieved the status of "Slow City" and being the member of Cittaslow International Network and the presence of the natural and cultural values related to the open spaces, which needs to be developed was effective in choosing the Siğacik settlement as the study area.

With the purpose of revealing the sustainability of traditional life and effects of the open spaces on local people's daily lives, this study, through a questionnaire, examined the;

- General characteristics of people and the study area,

- The expectations of the local people especially on open space uses,

- Natural and cultural landscape features of the settlement,

- Quality of the open spaces in terms of the identity of the settlement and the place of these open spaces in daily life.

\section{Material and Methods}

\subsection{The Siğacık Settlement and Its Environs}

Sığacık is a vicinity of the Seferihisar district of Izmir province. It is $4 \mathrm{~km}$ to Seferihisar and $46 \mathrm{~km}$ to İzmir (Figure 1). Siğacık is located on the north side of Seferihisar Dilek Peninsula, near the bay of Sığackk. From the beginning of early ages, there are samples of original architectural styles coming from the several different cultural impressions, which affected Siğacik. The settlement is important, because it has the archaeological ruins of Teos, which was one of 12 Ionic city - states. Siğacık Castle from the $16^{\text {th }}$ century, the monumental Siğacık Mosque, the Turkish bath, a small mosque and traditional Sığacık houses form the settlement pattern of the Sığacık Castle. Original monumental architecture examples of Sığacık survive challenging the time. However, in our day, this monumental structures and Seferihisar Sığacık Castle were damaged and cannot be protected adequately (Atalan, 2014). 

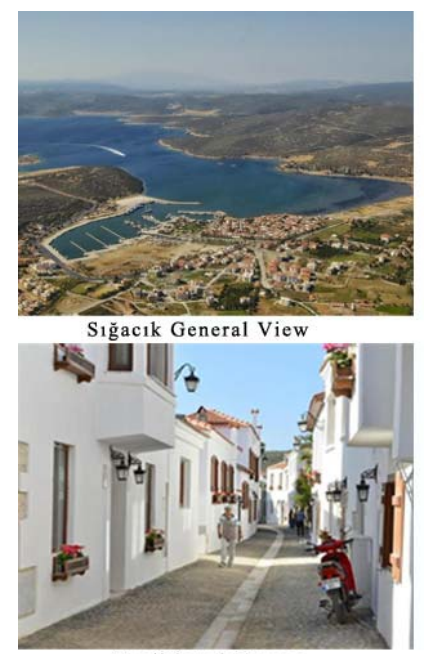

Traditional Houses

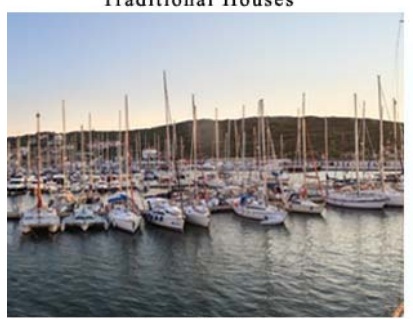

Teos Marina

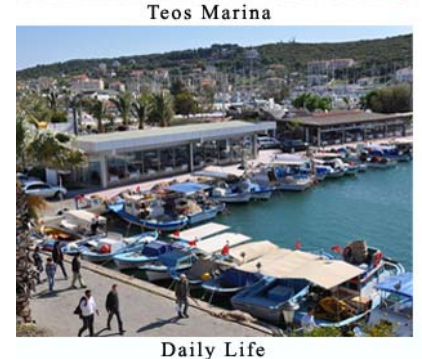

Daily Life
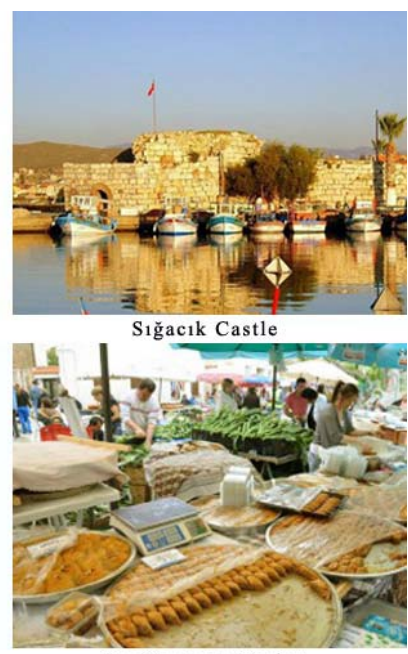

Eco Farmers Market

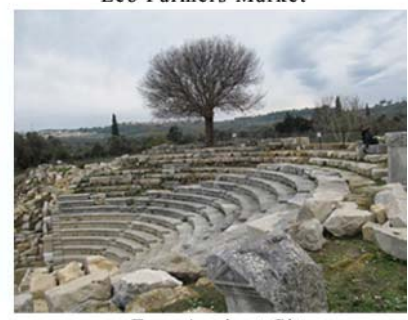

Teos Ancient City

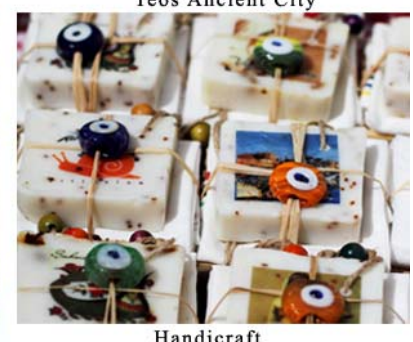

Figure 1. Photos from Siğacik Settlement

Sığacık is the showpiece of Seferihisar, which assumed the title of Turkey's first Cittaslow town in 2009 and contributes to the development of Seferihar tourism. In addition, as a part of "Siğacık Old City Streets Improvement Project", restoration works were carried out for 12 streets and market place in Kaleiçi and the perceptibility of the historic pattern of Sığacık is provided.

Every Sunday there is an open market in Siğacik to support the local producers for selling their products. In this way, local art, crafts, and tastes are sustained.

Sığacık also has a marina; on 06.21.2010, Teos Marina became operational with a capacity of 480 boats at sea, 80 boats on land, 30 that can be moored at channel docks in Seferihisar-Sığacik. (Teos Marina, 2015). In the marina there are restaurants boutique shops, cafes, coffee bars, Turkish bath and other social facilities and the marina provides every kind of service to the yachts (Turkiyeturizm.com, 2015).

Literary sources and development plans, photographs, notes and questionnaire forms are the supplementary materials in the study. 


\subsection{Structure of the Study}

The study was composed of 4 main phases called as definition of the subject, data collection, results and evaluation and synthesis (Figure 2).

Definition of the subject is comprised of the literature studies and the preliminary observations related to the study subject and the area. In addition, internet information and notes taken during the interviews with the local people constitute this section of the study.

Data collection: Methods of questionnaire was used in this study of the Siğacik Settlement. After the definition of the subject, an original questionnaire form was prepared to evaluate the opinions of local people a purely subjective approach. In the calculation of sample size of the questionnaire, the following method of Simple Random Sampling was used (Newbold, 1995) and a $90 \%$ confidence level and $0.10 \%$ sampling error was taken as the basis. Assistance was received from the Instructors of the Department of Agricultural Economy in the Faculty of Agriculture at Adnan Menderes University in the calculation of sample size of the questionnaire.

$$
\mathrm{N} p(1-\mathrm{p})
$$

$\mathrm{n}=$

$$
(\mathrm{N}-1) \sigma 2 \mathrm{px}+\mathrm{p}(1-\mathrm{p})
$$

The population of Siğacik (2329) from the results of the 2013 census was used as the "population size (N)" in the calculation (TUIK, 2014), and, at the end of the calculation, the sample size of questionnaire was determined as $66(65,77)$.

19 closed - ended questions (compulsory - elective questions and demographic questions) were posed to the respondents. The questionnaire was used to find out to evaluate the experience of open space by means of the available data. The questionnaires were carried out by means of face to - face interviews with local people selected randomly from the research area in November 2014.

Results: SPSS (v.10) was used for statistical analysis of the data which were obtained from the questionnaires in the evaluation stage of the results.

Evaluation and Synthesis: The literature studies and the information found from questionnaires were analyzed and evaluated using a holistic approach. Finally, recommendations were made to improve the quality of open spaces.

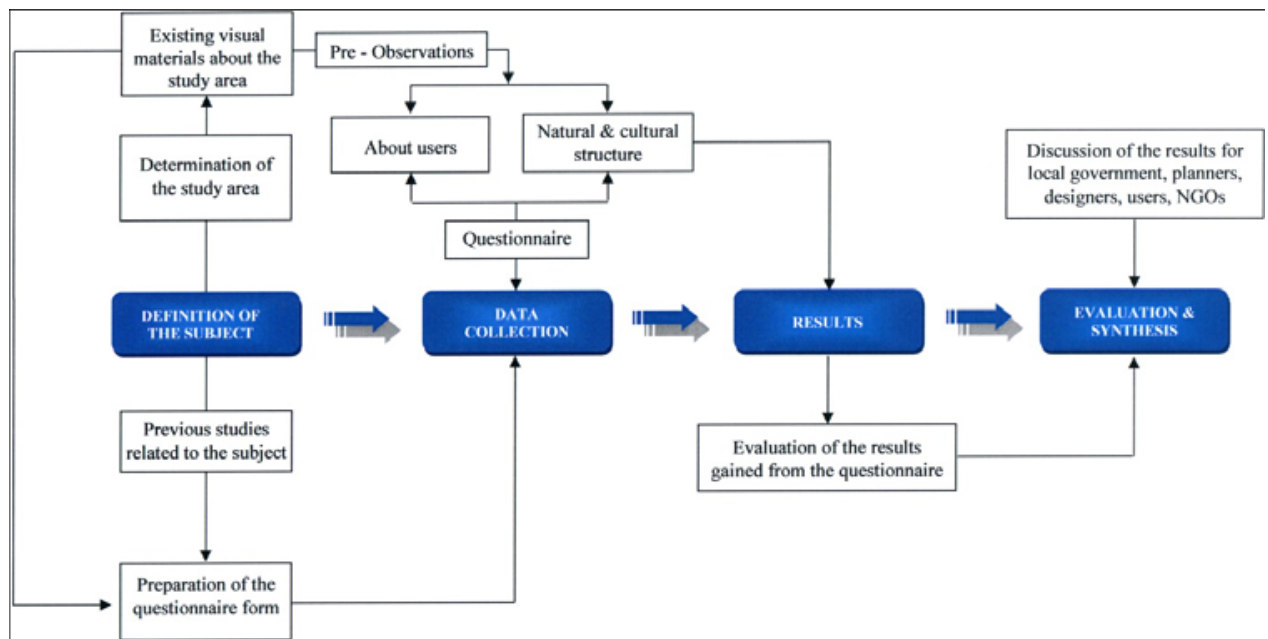

Figure 2. Method flow diagram 


\section{Results}

Face to face questionnaire method is used in this study in order to evaluate the outdoor life on the example of Cittaslow city, Seferihisar. In this context, the expectations of the local people from the use of open spaces are designated. Questionnaire, consisting of 19 questions, was carried out in Sığacık neighborhood of Seferihisar and demographic and compulsory - elective questions were posed to respondents. In order to test the consistency of the questionnaire, a trial questionnaire was conducted and the questionnaire form was developed and completed due to the results obtained from the trial questionnaire. After this, standardized questionnaire was conducted with 66 people who are selected randomly.

Firstly, demographic characteristics of the local people were determined. It is seen that $53.03 \%$ of the population are male, $46.97 \%$ of the population are female, and their ages vary between 18 and 89 . Approximately $50 \%$ of the population is under 45 years old. $24.24 \%$ of them are stand owners and $37.88 \%$ of them keep eating places such as food and beverage stands, cafe and restaurants. $59.09 \%$ of them sell their home products or partially their home products (Table 1). Most of the participants $(77.27$ \%) live in Sığacık and their time of life in Sığacık varies between 1 and 65. Reason of living in Siğac1k is also given in Table 2. According to this, the characteristics of Sığacık such as clean air and water and scenery features are mostly mentioned (27.42\%). 86.36\% of participants are happy to live in Sığacık and $72.73 \%$ them don't want to leave even if they have a chance (Table 2).

Questions on accessibility were also asked. It is found out that $59.09 \%$ of the respondents mention the accessibility and parking problem. On the other hand, most of them are partially or completely satisfied from public services $(71.21 \%$ ) (Table 3$)$.

Table 1. Demographics characteristics

\begin{tabular}{l|c|c|l|c|c} 
Sex & $\mathbf{( \% )}$ & $\mathbf{n}$ & Age & $\mathbf{( \% )}$ & $\mathbf{n}$ \\
\hline Male & 53.03 & 35 & $15-24$ & 7.57 & 5 \\
\hline Female & 46.97 & 31 & $25-34$ & 24.24 & 16 \\
\hline Profession & $\mathbf{( \% )}$ & $\mathbf{n}$ & $35-44$ & 16.67 & 11 \\
\hline Hotel / Pension Owner & 7.58 & 5 & $45-54$ & 22.73 & 15 \\
\hline Farmer & 7.58 & 5 & $55-64$ & 19.70 & 13 \\
\hline Public officer & 1.51 & 1 & $65-89$ & 9.09 & 6 \\
\hline Selling stand owner & 24.24 & 16 & Education & $\mathbf{( \% )}$ & $\mathbf{n}$ \\
\hline Eating place owner & 37.88 & 25 & Primary School & 28.79 & 19 \\
\hline Other & 21.21 & 14 & Middle School & 33.33 & 22 \\
\hline Local producer & $\mathbf{( \% )}$ & $\mathbf{n}$ & High School & 15.15 & 10 \\
\hline Yes & 34.85 & 23 & Vocational Scholl & - & - \\
\hline Partially & 24.24 & 16 & BSc & 22.73 & 15 \\
\hline No & 40.91 & 27 & MsC & - & -
\end{tabular}

Table 2. Residency

\begin{tabular}{l|c|c|l|c|c} 
Place of residence & $\mathbf{( \% )}$ & $\mathbf{n}$ & Inhabitancy in Sığacık (year) & $\mathbf{( \% )}$ & $\mathbf{n}$ \\
\hline Sığacık & 77.27 & 51 & $1-20$ & 4.55 & 3 \\
\hline Seferihisar & 13.64 & 9 & $21-40$ & 36.36 & 24 \\
\hline İzmir & 09.09 & 6 & $41-60$ & 48.49 & 32 \\
\hline Pleasure of living in Sığacık & $\mathbf{( \% )}$ & $\mathbf{n}$ & $61-65$ & 10.60 & 7 \\
\hline Yes & 86.36 & 57 & Reason of living in Sığacık & $\mathbf{( \% )}$ & $\mathbf{f}$ \\
\hline Partially & 7.58 & 5 & Born in Sı̆̆acık & 21.51 & 40 \\
\hline No & 6.06 & 4 & Air / Water / Scenery & 27.42 & 51 \\
\hline Wish to leave from Sığacık & $\mathbf{( \% )}$ & $\mathbf{n}$ & Work in Sı̆̆acık & 23.65 & 44 \\
\hline Yes & 27.27 & 18 & Tranquility & 26.34 & 49 \\
\hline No & 72.73 & 48 & Other & 1.08 & 2
\end{tabular}


Table 3. Accessibility

\begin{tabular}{l|c|c|l|c|c} 
Accessibility problem & $\mathbf{( \% )}$ & $\mathbf{n}$ & Private car & $\mathbf{( \% )}$ & $\mathbf{n}$ \\
\hline Yes & 36.36 & 24 & Yes & 53.03 & 35 \\
\hline Partially & 22.73 & 15 & No & 46.97 & 31 \\
\hline No & 40.91 & 27 & Pleased from public services & $\mathbf{( \% )}$ & $\mathbf{n}$ \\
\hline Car park problem & $\mathbf{( \% )}$ & $\mathbf{n}$ & Yes & 45.45 & 30 \\
\hline Yes & 36.36 & 24 & Partially & 25.76 & 17 \\
\hline Partially & 22.73 & 15 & No & 28.79 & 19 \\
\hline No & 40.91 & 27 & & &
\end{tabular}

A large majority of the people are aware that Sığacık - Seferihisar is a Cittaslow city (98.48 \%) and approximately $60 \%$ of the respondents think positively about the Cittaslow status of the settlement and its effects on their daily life. Most of the people find the settlement livable (Table 4).

When the using purposes of the open spaces are questioned, it can be seen that there is a balanced distribution between the responses. On the other hand, shopping is the most preferred activity $(27.34 \%)$ (Table 5).

Questions on sensorial evaluation were also posed to the respondents. Most of the people find Siğacık safe $(96.97 \%)$ and peaceful $(93.94 \%)$ and they find Sığacık authentic, simple and stable respectively (Table 6).

Table 4. Effects of being Cittaslow city

\begin{tabular}{l|c|c|l|c|c} 
Aware of being citta slow & $\mathbf{( \% )}$ & $\mathbf{n}$ & Effects of citta slow & $\mathbf{( \% )}$ & $\mathbf{n}$ \\
\hline Yes & 98.48 & 65 & Positive & 57.58 & 38 \\
\hline No & 01.52 & 01 & Negative & 15.15 & 10 \\
\hline Pleased from popularity & $\mathbf{( \% )}$ & $\mathbf{n}$ & No effects & 27.27 & 18 \\
\hline Yes & 68.18 & 45 & Livability & $\mathbf{( \% )}$ & $\mathbf{n}$ \\
\hline Partially & 15.15 & 10 & Yes & 62.12 & 41 \\
\hline No & 16.67 & 11 & Partially & 21.21 & 14 \\
\hline & & & No & 16.67 & 11
\end{tabular}

Table 5. Physical characteristics

\begin{tabular}{l|c|c} 
Using purposes of open space & $\mathbf{( \% )}$ & $\mathbf{f}$ \\
\hline Eating - Beverages & 19.53 & 25 \\
\hline Shopping & 27.34 & 35 \\
\hline Sitting / Chatting & 24.22 & 31 \\
\hline Walking / Wandering & 23.44 & 30 \\
\hline Other & 5.47 & 7
\end{tabular}

Table 6. Sensorial evaluation

\begin{tabular}{c|c|c|c|c|c} 
Adjectives & $\mathbf{n}$ & $\mathbf{\%}$ & $\mathbf{n}$ & $\mathbf{\%}$ & Adjectives \\
\hline Active & 26 & 39.39 & 40 & 60.61 & Stable \\
\hline Peaceful & 62 & 93.94 & 4 & 06.06 & Disturbed \\
\hline Safe & 64 & 96.97 & 2 & 03.03 & Unsafe \\
\hline Simple & 41 & 62.12 & 25 & 37.88 & Disorganized \\
\hline Authentic & 44 & 66.67 & 22 & 33.33 & Ordinary \\
\hline
\end{tabular}

\section{Evaluation and Synthesis}

It can be seen from the results that most of the people earn money from selling stands and food and beverage places. Especially the marketplace where people sell their local products on selling stands are supported by the municipality and this fit the spirit of the Cittaslow city. 50 
$\%$ of the people are younger than 45 years old which means that people earn their lives from the activities supported by Cittaslow sense. People are not in need of leaving the place to earn money. From the questionnaire responses, we can understand that most of them live in Siğacik more than 40 years. In this context, it can be seen that Cittaslow movement has affected their life positively and has created new job opportunities.

When someone observes the settlement it can be easily seen that daily life passes outside the houses. There is not an urban chaos and people are happy to live and work in Siğac1k. Especially on Sundays the market place brings great vitality / dynamism to the settlement. It is known that The Slow City movement aims to protect and enhance urban liveability and quality of life and maintain local uniqueness. "Sığacık Old City Streets Improvement Project" has affected the settlements image positively and perceptibility of the historic pattern of Sığacik is provided. On the other hand, especially on Sundays the settlement gets crowded as the visitors draw away from the big cities, want to buy the local products and wander in the market place and take the air. This results in need of car parking and brings a dilemma that "Slow City" turns into a crowded one. In this context, new parking areas have to be designed. Regardless, Sığacık is safe and peaceful, authentic, simple and stable for most of the people. These positive features of Siğacik, which affects the image of the settlement must be protected and improved.

\section{References}

Afd, 2015. Cittaslow: Sürdürülebilir Yerel Kalkınma Modeli. Retrieved from web site: http://www.afd.fr/webdav/shared/portails/pays/turquie/Evenements/mustafa_tunc_soyer\%20TR.pdf, Accessed: 03.02.2015.

Atalan, Ö. (2014). Consolidation of Castle Gates; Case Study of Seferihisar Sığacık Castle Gates. International Journal of Social Science, 30, 357 - 376.

Cittaslow Türkiye, 2015. Cittaslow Felsefesi. Retrieved from web site: http://cittaslowturkiye.org/?page id=1063, Accessed: 03.02.1015.

Cittaslow.org, 2015. Cittaslow 2 List. 2 Retrieved from web site: http://www.cittaslow.org/download/DocumentiUfficiali/CITTASLOW LIST november2014.p df, Accessed: 03.01.2015.

Knox, P.L. (2005). Creating Ordinary Places: Slow Cities in a Fast World, Journal of Urban Design, 10(1).

Mayer, H. and Knox, P. L. (2006). Slow Cities: Sustainable Places in a Fast World. Journal of Urban Affairs. 28(4), $321-334$.

Miele, M. (2008). Citta 'Slow: Producing Slowness against the Fast Life. Space and Polity. 12 (1), 135 - 56.

Newbold, P. (1995). Statistics for Business and Economics, New Jersey: Prentice Hall.

Pink, S. (2009). Urban Social Movements and Small Places, Slow Cities as sites of activism. City, 13(4), 451 465.

Radstrom, S. (2011). A Place-Sustaining Framework for Local Urban Identity: An Introduction and History of Cittaslow. IJPP - Italian Journal of Planning Practice, I(1- 201), 90 - 113.

Teos Marina, 2015. Marina Teos Marin. Retrieved from web site: http://www.teosmarina.com.tr/icerik/106/teos-marin, Accessed: 05.01.2015.

TUIK, 2014. Prime Ministry Republic of Turkish Statistical Institute. Retrieved from web site: http://tuikapp.tuik.gov.tr/adnksdagitapp/adnks.zul, Accessed: 10.11.2014.

Turkiyeturizm.com, 2015. Teos Marina Törenle Açllyor. Retrieved from web site: http://www.turkiyeturizm.com/news print.php?id=28551, Accessed: 06.02.2015.

Vize Municipality, 2015. Cittaslow Tantım. Retrieved from web site: http://www.vize.bel.tr/CittaslowTanitim.html, Accessed: 03.02.2015.

\section{References for Photos in Figure 1}

Sığacık General View: Retrieved from web site: https://seferihisarcittaslow.files.wordpress.com/2010/08 /cemali_sgck liman.jpg, Accessed: 26.02.2015. 
Sığacık Castle: Retrieved from web site: http://www.sehirfirsati.com/deals/izmir/festivalyayin/8484222, Accessed: 26.02.2015.

Traditional Houses: Retrieved from web site: http://emlak.ensonhaber.com/dunyanin-en-eski-tatil-koyusigacik-kaleici-2014-12-09.html, Accessed: 26.02.2015.

Eco Farmers Market: Retrieved from web site: http://www.sigacikpazari.com/sigacik, Accessed: 26.02.2015.

Teos Marina: Retrieved from web site: http://www.teosmarina.com.tr/gorsel-galeri/7eebd010/30857af4, Accessed: 26.02.2015.

Teos Ancient City: Retrieved from web site: http://kadirbekci53.blogspot.com/2014/01/tarihi-koruyanagac.html, Accessed: 26.02.2015.

Daily Life: Retrieved from web site: https://gezmeciler.files.wordpress.com/2013/04/dsc 0040.jpg, Accessed: 26.02 .2015 .

Handicraft: Retrieved from web site: https://s8e0.wordpress.com/2013/04/24/teos-sigacik, Accessed: 26.02.2015. 